\title{
E HD現象を応用した回転型アクチュエータの開発*
}

\author{
ーEHDモータの開発一 \\ 寺 阪 澄 孝 ${ }^{*}$ 藤 周** 三 井和 幸*
}

Development of the Rotation Type Actuator using EHD Phenomenon

- Development of the EHD Motor -

Sumitaka TERASAKA, Shu KUDOU, Kazuyuki MITSUI

\begin{abstract}
The purpose of this study was development of the rotation type actuator that applied the EHD phenomenon. The EHD is a phenomenon that generates the flow in the insulating fluid by applying a high voltage electric field. In this study, firstly, the electrode arrangement which makes the strong EHD phenomenon was investigated and the EHD motor applying that electrode arrangement was developed. In the next step, the EHD motor using the developed electrode arrangement was manufactured as an experiment. Then, the electrode arrangement of the EHD motor was changed, and the performance change of the EHD motor was examined.
\end{abstract}

Key words: EHD, electrohydrodynamics, motor, actuator, electrode

\section{1. 緒言}

EHD とは Electrohydrodynamics (電気流体力学) の略称で, 絶縁性流体に直流電圧を印加すると電極間に流れが発生する現

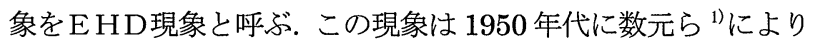
発見されていたが, 従来EHD現象に関する研究にはシリコー ンオイルや機械油等の流体が用いられ，これらの流体は発生す る圧力が数 $100 \mathrm{~Pa}$ と弱いものであった. また, 電圧印加のため の電極配置の研究も十分には行われておらず低い圧力しか得ら れなかった. そのため, EHD現象は応用が期待されていたに もかかわらずアクチュエータなどへの応用には至らなかった. しかし, 近年D B D N (ドデカン 2 酸-n一ブチル)等の強い流れを 発生する流体が見出され，現在ではE HDに関する多くの研究 が行われている ${ }^{2) \sim 4}$. 特にE HD現象に類似した研究として横 田らのグループでは，E C F (Electro Conjugate Fluid)と呼ば れるジェット流を発生する特殊な液体を用い, 様々なアクチュ エータの開発に成功し機能性流体を応用したアクチュエータ開 発の先駆けとなり，その応用が期待されている ${ }^{5)}$. .

E HD現象をアクチュエータへ応用した場合, 電圧印加によ り直接流体を駆動させるため機構部品をほとんど含まず, また 部品点数が少なく信頼性が高い. さらに, 流体駆動であるため 流体の圧縮等により機器自体が柔らかさを有するため, 直接人 間に接する機器など柔軟性を有するアクチュエータへの応用が 期待できる.

既に，空気圧等を利用した流体駆動型において，柔軟性を有 するアクチュエータの開発が実施されているが，コンプレッサ や配管等が必要となりシステムが大型化することが懸念される. また, 電磁モー夕等を用い制御により柔軟性を得る方法では, システムが小型であるものの, 制御が複雑でアクチュエーター の過負荷の回避など技術的な問題も多い. E HD現象をアクチ ユエータへ利用できれば, 電磁モータの有するシステムが小型

\footnotetext{
* 原稿受付 平成 19 年 2 月 26 日

* 正会 員 東京電機大学 (東京都千代田区神田錦町 2-2)

** 東京電機大学大学院 先端科学技術研究科
}

であるという利点と, 流体駆動型による機構的な柔軟性を有す るという利点を併せもつ，新たなアクチュエータが実現できる と考えられる.

本研究では，工業的に多く用いられ，その応用範囲も広いと 考えられる回転型のアクチュエータに着目した．まず， E HD 現象を利用したアクチュエータの開発が可能であるか検討する ために, E HD現象を発生する基本的な電極構造を改良した. さらにアクチュエータに適した新たな電極構造を考案し, $\mathrm{EH}$ Dモータと呼ぶ回転型アクチュエータの開発を行った. また, これらの開発したアクチュエータについて基礎的な特性と電極 形状による性能の変化を実験的に検討した.

\section{2. 電極構造の考案}

EHD現象は不平等電界中において強い流動を発生するとさ れている ${ }^{9}$ ため, 密から疎, または疎から密になるような不平等 電界を形成する電極 配置として, 図 1 (a) に示す平板電極と線 電極の電極配置に着 目した.この電極配 置において線電極を プラス, 平板電極を

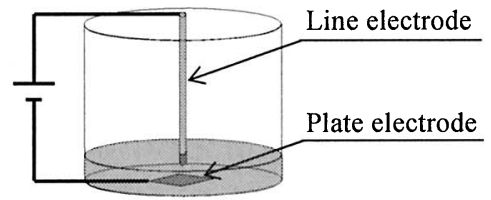

(a) Schematic diagram of electrode configuration
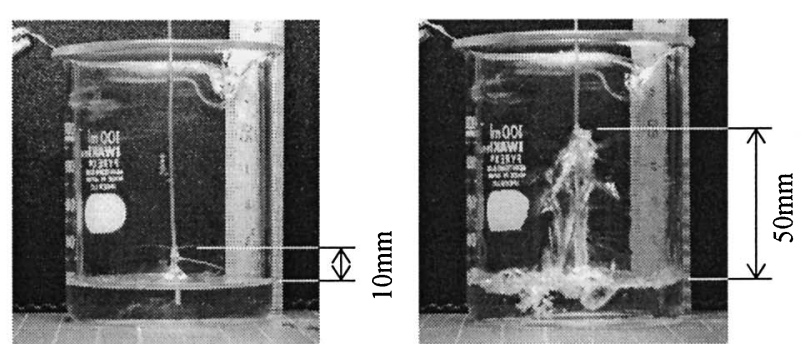

(b) Photograph of EHD phenomenon in silicone oil

(c) Photograph of the fluorine-containing insulation fluid rising up the line electrode

Fig.1 EHD phenomenon by plate electrode and line electrode 
GND としこれらを絶縁性液中に配置し直流高電圧を印加する と, 印加電圧 $10 \mathrm{kV}$ で, 絶縁性液体としてシリコーンオイル を用いた条件において，図 1 (b)のように平板電極から線電極 へ向けて活発な流体の上昇が確認された。流体が上昇した高さ は, 印加電圧 $10 \mathrm{kV}$ 時において最大で約 $10 \mathrm{~mm}$ であった. さら に，我々が調整したフッ素系の絶縁液体を用い同条件にて実験 を行った結果, 図 1 (c)に示すように液面上昇は $40 \mathrm{~mm}$ に達した. この流動を一方向へ流すことにより力を取り出すことが可能で あれば，EHD現象を応用することによる利点である，機械要 素が少なく，また柔軟性に富んだアクチュエータの開発が可能 であると考えた，そして，これらを踏まえ，本研究において開 発するアクチュエータを，工業的に広く応用され，また検討が 行いやすいことから，回転型のアクチュエータとした，そして 線電極と平板電極の電極形状を, 回転体の駆動に適する電極形 状へ変化させるため, 以下に示すような形状変更を考案した.

図 2 (a) は図 1 の液面上昇を発生する電極構造の模式図で, 絶 縁性液体中に配置した線電極と平板電極の電極対において， $\mathrm{E}$ $\mathrm{HD}$ 現象による流動は平板電極から線電極に沿うように上方向 へ発生する.これを図 2(b)のように 90 度回転させると，その 流動も横方向に発生する. 次に, 図 2 (c) のように線電極を平板 電極の下側に移動させると流動も線電極と共に移動する.さう に，線電極を延長すると流れは線電極の両側を沿うように発生 する(図 2(d)). そして，平板電極を斜めに傾けることにより， 平板電極から発生する流れは一方向に生じ, 図の矢印に示す方 向に平板電極は流れの反作用を受ける(図 $2(\mathrm{e})$ )。ここで，均等 に流れが発生するように, 線電極の形状を平面にする(図 2 (f)). さらに，平面にした電極を環状に変形することにより，図 $2(\mathrm{~g})$

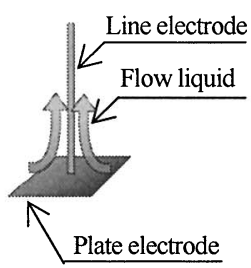

(a) Plate electrode and line electrode

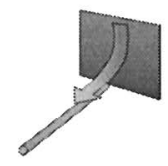

(c) The line electrode is moved below

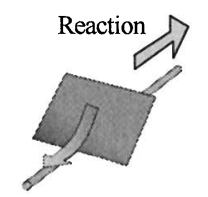

(e) The plate electrode is inclined

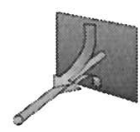

(b) The electrode is rotated by 90 degrees

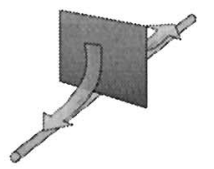

(d) The line electrode is extended.

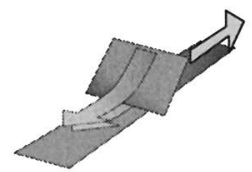

(f) The line electrode is made like the board

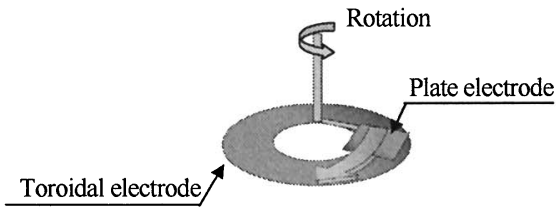

(g) The board electrode is made a toroidal

Fig.2 Design of electrode shape
に示す回転運動を得ることが可能となり，斜めに傾けた平板電 極に出力軸を取り付け，EHD現象を回転運動として取り出す 回転型アクチュエータの製作が可能であると考えた.

\section{3. 開発した回転型アクチュエータ}

考案した電極形状を用いてE HD回転型アクチュエータの製作 を行った. 図3(a)に示すように，アルミニウム板により製作した 環状電極をアクリル樹脂により製作した底部に貼り付け，絶縁性 液体を入れるための容器となる筒を，内部の動作が観察しやすい ようにアクリル樹脂で製作しその上部に取り付けた。 ふた部には ベアリングを軸受けとして取り付け，ステンレス製の出力軸を取 り付けたアルミニウム製の平板電極を配置した．各寸法は容器部 分の内径 $60 \mathrm{~mm}$, 高さ $40 \mathrm{~mm}$ ，ふた，底部はそれぞれ縦・横各 $100 \mathrm{~mm}$, 高さ $20 \mathrm{~mm}$, 出力軸の直径 $3 \mathrm{~mm}$ とした. また，環状 電極にはプラス電圧を印加し，平板電極は GND とし，回転する 平板電極へベアリングから出力軸を通し接地する構造とし た. 図 3(b) は製作したアクチュエータの外観である.このように, 我々が考案した電極構造を用い，新たに開発したアクチュエータ をEHDモータと呼ぶこととした.

\section{4.＼cjkstart電極形状の違いによる性能評価実験}

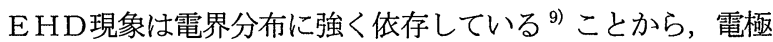
配置がE HDモータの性能にも反映されると考えられる. また, EHDモータ内部の平板電極はロータとして絶縁性液体を掻き 分けて回転運動を行うため流体力学的な抵抗を受ける. そして, これら電界と流体の影響は相互にEHDモータの性能へ影響を 及ぼすと考えられる，そのため， EHD現象により発生する流 れをより効率的に取り出すことが可能で，かつ流体力学的に回

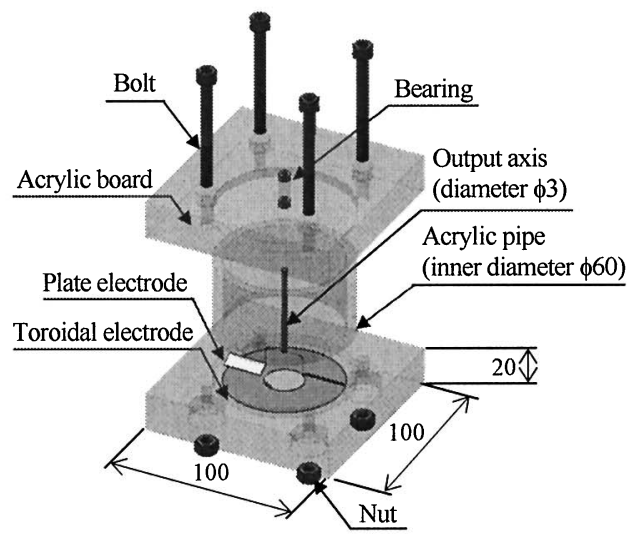

(a) Structure of the actuator

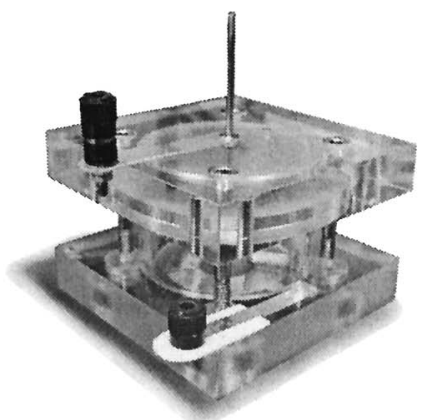

(b) Photograph of the actuator

Fig.3 Developed the actuator which named the EHD motor 
転運動を妨げにくい電極形状を解析的に検討することは困難で あると考えた．そこで電界の影響と流体から受ける流れの影響 が最も表れると考えられる電極形状の中で図 4 に示した，平板 電極角度, 平板電極長さ, 環状電極幅の 3 種にパラメータを限 定し, これらを変化させたときの無負荷回転数と始動トルクを 測定することにより，EHDモータの性能の違いを検討した.

\section{1 実験方法}

4. 1.1 無負荷回転数の測定

使用した実験装置を図 5 に示すＥHDモータには直流電源 （松定プレシジョン製 PL-18-2, 出力電圧 0 ～18V） から昇圧 器（松定プレシジョン製 $\mathrm{HV}-10 \mathrm{P}$, 最大出力電圧 $10 \mathrm{kV}$ ) を介し 電圧を印加した. そして, 無負荷回転数の測定には, 光学式回 転計（横河電気製ポケット回転計）とEHDモータの出力軸に 取り付けた反射板を用い，非接触により出力される回転数を $\mathrm{A} / \mathrm{D}$ 変換（共和電業社製, PCD-320A）した後コンピュータに 記録した.

\subsection{2 始動トルクの測定}

始動トルクの測定装置は図 6 に示すように, ロードセル（共 和電業社製，LVS-200GA，定格 200gf），ロードセル用アンプ (共和電業社製, $P C D-300 A)$, コンピュータ，直流電源，昇圧 器より構成した.

EHDモータの出力軸に伸縮の無い糸を巻き付け，ロードセ ルにより測定したモータの出力軸が系を巻きつける力をコンピ ュータに記録した. その記録した值と, 出力軸の半径から始動 トルクを算出した. なお, 無負荷回転数の測定と同様に電圧を 印加することによりEHDモータを駆動した.

\section{2 実験条件}

図 7 に示すように，3 種類のパラメータは，平板電極角度は $15,30,45,60^{\circ}$ の 4 種類, 平板電極長さは $5,7,10 \mathrm{~mm}$ の 3 種類, 環状電極幅は $5,10,20 \mathrm{~mm}$ の 3 種類とし, これらは

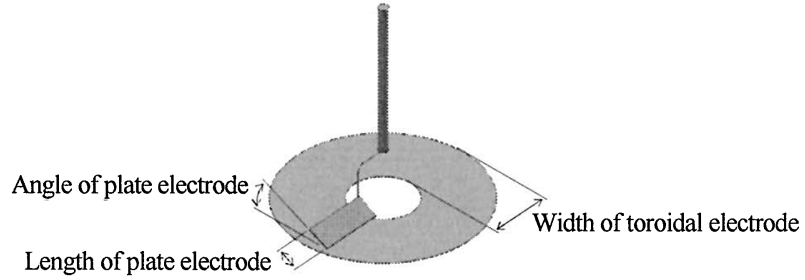

Fig.4 Parameter of electrode shape

DC Power supply

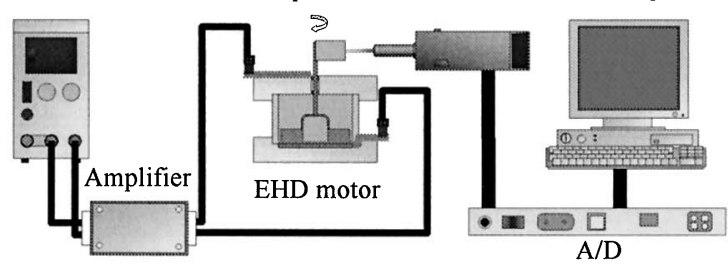

Fig.5 Measurement device of no load rotational speed

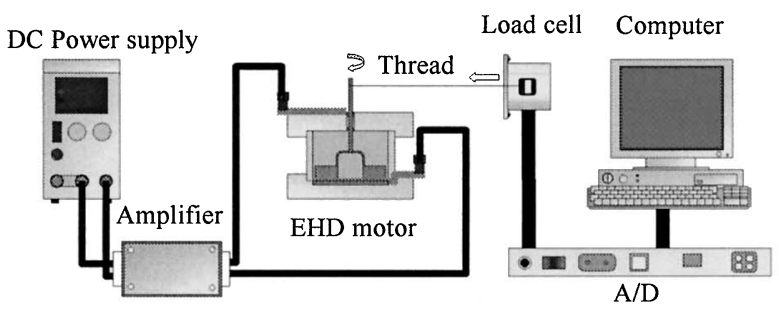

Fig.6 Measurement device of starting torque
相互に影響し合うと考えられることから，全ての組合せである 36 通りで測定を行った. また, 印加電圧は使用した装置の最大 出力電圧から $1 \mathrm{kV}$ 間隔で $10 \mathrm{kV}$ までとした. なお, 絶縁性の液 体はEHDモータ内部に完全に満たし, 最も電極間距離が小さ い環状電極表面と平板電極先端との距離を $2 \mathrm{~mm}$ とした. なお, 平板電極の幅については回転半径が変化してしまうためパラメ ータとせず $20 \mathrm{~mm}$ に固定して実験を行った。

4.3 結 果

図 8 に平板電極角度 4 種類, 平板電極長さ 3 種類, 環状電極 幅 3 種類のパラメータの全ての組合せである 36 通りの条件に おける, 印加電圧と無負荷回転数の関係を示す. また図 9 に印 加電圧と始動トルクの関係を示す. なお，二つのグラフとも最 大の值を示した組合せの結果を黒で, その他の組合せによる結 果を灰色で示した.

図 8 に示すように, 全てのパラメータの組合せにおいて無負 荷回転数の測定を行った結果, 印加電圧 2 から $6 \mathrm{kV}$ において全 ての条件でEHDモータの動作が開始し, 印加電圧を上昇させ るに伴い無負荷回転数も比例的に上昇する傾向が表れた. 最も 高い無負荷回転数を示した電極の組合せは(図中の黒で示した) 平板電極角度 $30^{\circ}$, 平板電極長さ $7 \mathrm{~mm}$, 環状電極幅 $20 \mathrm{~mm}$ で, 最大回転数は $314 \mathrm{rpm}$ であった。 また,この時の電流值は

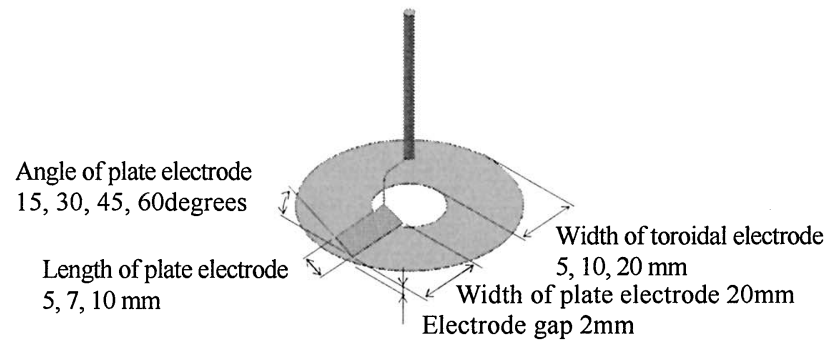

Fig.7 Measurement condition of the EHD motor

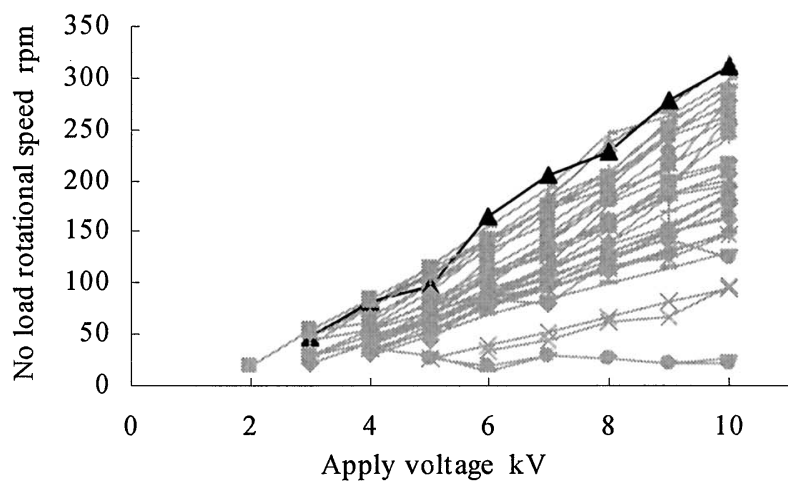

Fig.8 Relation between applied voltage and no load rotational speed

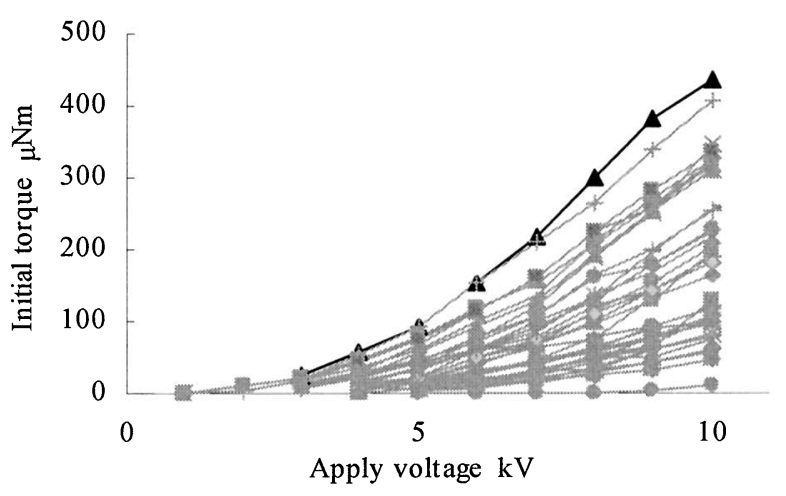

Fig.9 Relation between applied voltage and initial torque 
$20 \mu \mathrm{A}$ で消費電力は $0.2 \mathrm{~W}$ となった.

図 9 に示すように, 始動トルクにおいては, 印加電圧 $2 \mathrm{kV}$ か ら $4 \mathrm{kV}$ において全ての条件でE HDモータの動作が開始しトル クを発生した. 印加電圧を上昇させるに伴い始動トルクは二次 曲線的に上昇する傾向が表れた。 そして, 最も高い始動トルク を示した電極の組合せは(図中の黒で示した) 平板電極角度 $30^{\circ}$ ， 平板電極長さ $7 \mathrm{~mm}$, 環状電極幅 $20 \mathrm{~mm}$ で最大トルク $435 \mathrm{Nm}$ であった. また，この時の電流值は $26 \mu \mathrm{A}$ で消費電力は $0.26 \mathrm{~W}$ となった.

\section{5. 考 察}

4 章 3 節において, 電圧により E HDモータの回転数, トル クの調節が可能であることを確認できた．また，いずれの実験 においても電流值は約 $20 \mu \mathrm{A}$ 程度であったことから，EHDモ 一タに掛かる負荷が最大である始動トルク測定の状態であって も, 無負荷の消費電力と比較して殆ど変化はないと考えられる. このことから，EHDモータは動作中の過負荷により出力軸が 止まっても，一般的な電磁モータのように過電流が流れず，ま た過電流に対する制御を行う必要が無いため, 負荷に対する柔 軟性を有していると考えられる.

次に, 最も高い性能を示した平板電極角度 $30^{\circ}$, 平板電極長さ $7 \mathrm{~mm}$, 環状電極の幅 $20 \mathrm{~mm}$ の組合せを基準として, このパラメ 一タの前後でどのように始動トルクと無負荷回転数に変化が現 れたのか検討を行うために, 横軸に変更したパラメータをとり, 縦軸に回転数, トルクをとったグラフを新たに作成した.

5.1 平板電極角度と無負荷回転数・始動トルクの関係

図 10 に平板電極の角度と無負荷回転数, 及び始動トルクの関 係を示す．なお，このグラフでは平板電極の角度の影響のみを 見るため, 平板電極長さ $7 \mathrm{~mm}$, 環状電極幅 $20 \mathrm{~mm}$ は固定とし ている. また，0〜 $10 \mathrm{kV}$ までのグラフは同様の傾向を示したの で, 安定した動作が可能であった最も低い印加電圧 $4 \mathrm{kV}$ と最大 印加電圧 $10 \mathrm{kV}$ とその中間電圧 $7 \mathrm{kV}$ のみのグラフを示す.

平板電極角度の変化に対する性能の違いを見ると, $4,7,10 \mathrm{kV}$ のいずれの電圧においても平板電極の角度 $30^{\circ}$ を最大值とし, 無負荷回転数, 始動トルク共に凸形の傾向が得られた. これは, 平板電極角度が電極間に出来る電界の形状に影響を及ぼしてい るためであると考えられる. そこで, 有限要素法 (ANSYS. INC 社製，ANSYS）による電界解析を行った(図 11)。モデルは平板 電極と環状電極をEHDモータの側面から見た 2 次元形状を模 式的に現したもので, 平板電極が環状電極と平行な $0^{\circ}$, 最大值 を示した $30^{\circ}$ の 2 種類である. その他の形状は実際のE HDモ

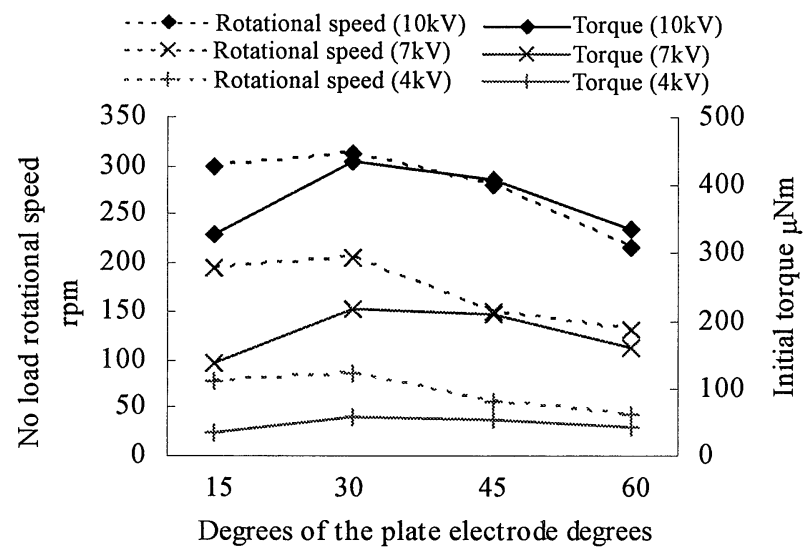

Fig.10 Relation between angle of plate electrode and rotational speed and relations between angle of plate electrode and torque
一タと同様にし，電極間隔は $2 \mathrm{~mm}$ ，印加電圧は $10 \mathrm{kV}$ とした。 図の色は電界強度を表し, 薄い色は電界強度が強く, 濃くなる に伴い電界強度は弱くなることを示している.

図 11 (a)に示すように平行の電極配置において平板電極と環 状電極間は均一な電界分布となり, 図 11 (b)のように角度が大き くなると，不平等な電界分布が電極間に形成され，平板電極先 端が密となり, 環状電極面が疎な電界が形成される．E HD現 象は不平等電界により, より強い流れが発生するため, 角度が 浅く均一な電界分布を形成し易い平行に近い電極配置では始動 トルク・無負荷回転数ともに低下寸ると考えられる.

また，平板電極は液体中を移動するため流動抵抗が生じ，電 極角度の増加に伴い無負荷回転数が減少したと考えられる.さ らに，EHDモー夕は平板電極から流れを発生させ反作用で回 転するがそれと同時に，絶縁性液体も力を受けているため流体 はEHDモータの回転と逆方向に流れる. そして, 発生した流 れは円筒内を移動する過程で減速するものの平板電極を押し戻 そうとする力として働いていると考えられる. そのため, 平板 電極角度が大きくなるのに伴い，電極を固定して測定する始動 トルクであっても無負荷回転数と同様に流体の抵抗によりトル クが減少したと考えられる. そして，これらの相互作用により 無負荷回転数，始動トルク共に平板電極角度 $30^{\circ}$ で值が最大に なったと考えられる. なお，この実験で考案した平板電極によ る電極構造の解析には E HD現象と流体力学的な影響を同時に 考慮する必要があり，EHD現象の発生メカニズムについては 数式化されているものの, 流体力学との複合解析は困難である ため, 詳細な検討は今後の課題であると考えている.

5.2 平板電極長さと無負荷回転数・始動トルクの関係

図 12 に平板電極長さと無負荷回転数及び始動トルクとの関係 を示す，なお，平板電極長さの影響のみを見るため，平板電極 角度 $30^{\circ}$ ，環状電極幅 $20 \mathrm{~mm}$ は固定とした. また，5 章 1 節 と同様に印加電圧 $4,7,10 \mathrm{kV}$ のグラフを示す.

平板電極長さの変化に対する性能の違いを見ると，いずれの 電圧においても平板電極の長さ $7 \mathrm{~mm}$ を最大にして無負荷回転

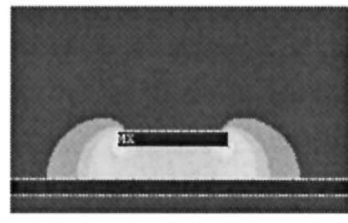

(a) Electric field distribution in electrode arranged in parallel

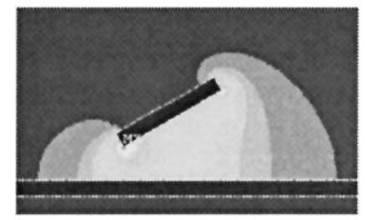

(b) Electric field distribution of plate electrode inclined at 30 degrees to the horizontal
Fig.11 Analytical result of electric field distribution by finite element method

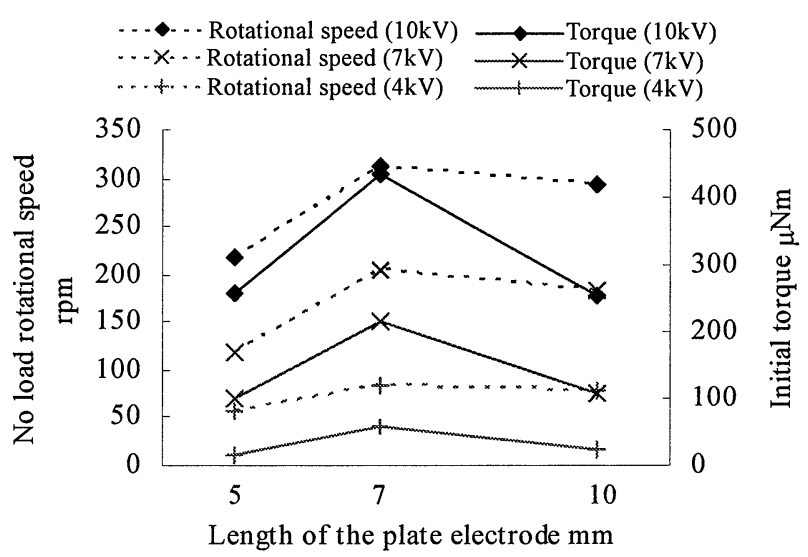

Fig.12 Relation between length of plate electrode and rotational speed and relations between length of plate electrode and torque 
数，始動トルク共にグラフの形状は凸になった.

この理由として, 図 13 (a)に示すように平板電極が極端に短く ほぼ点に近い状態では，発生する流れは左右対称になり，回転 方向が定まらず回転方向を打ち消すように流れるため, 無負荷 回転数, 始動卜ルク共に小さくなると考えられる.これに対し, 図 13 (b) に示すように, ある程度の長さをもたせた平板電極にお いては，電極を沿うように一方向に流れが発生するため，平板 電極には整流作用があると考えられる．また，平板電極の角度 と同様に平板電極の長さに関しても長すぎる場合，平板電極を 押し戻す流れが大きな抵抗となり性能が低下すると考えられる このことから, 平板電極にはある程度の長さが必要であり, 今 回の条件においては $7 \mathrm{~mm}$ が最大であったと考えられる.

5.3 環状電極幅と無負荷回転数・始動トルクの関係

図 14 に環状電極幅と無負荷回転数及び始動トルクとの関係を 示す．なお，環状電極幅の影響のみを見るため，平板電極角度 $30^{\circ}$ ，平板電極長さ $7 \mathrm{~mm}$ は固定とした．また，5 章 1 節と同 様に印加電圧 $4,7,10 \mathrm{kV}$ のグラフを示す.

グラフは右上がりとなり，環状電極幅 $20 \mathrm{~mm}$ において無負荷 回転数，始動トルクともに最大となった．環状電極幅が，平板 電極の底辺と同じ幅のときは(図 15(a)), 電界が均一なため流れ が一方向に発生し回転が起こると考えられる.これに対し，環 状電極の幅が狭いと (図 $15(\mathrm{~b})$ ), 平板電極の中央では図 15 (a) と 同様に流れが発生するが，平板電極の両端は電極間隔が広いた め電界が弱く, 流れも図 15 (a) に比べ弱くなってしまい, 回転が 起こり難くなる. そのため, 環状電極幅 $20 \mathrm{~mm}$ のとき最大值を 示したと考えられる.

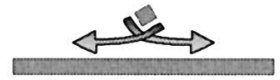

(a) When the plate electrode is short (b) When the plate electrode is long

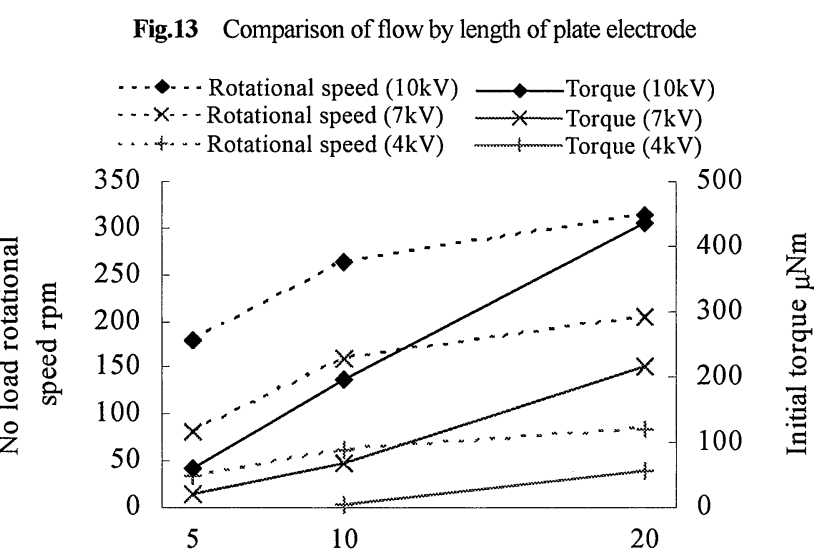

Width of the toroidal electrode $\mathrm{mm}$

Fig.14 Relation between length of plate electrode and rotational speed and relations between length of plate electrode and torque
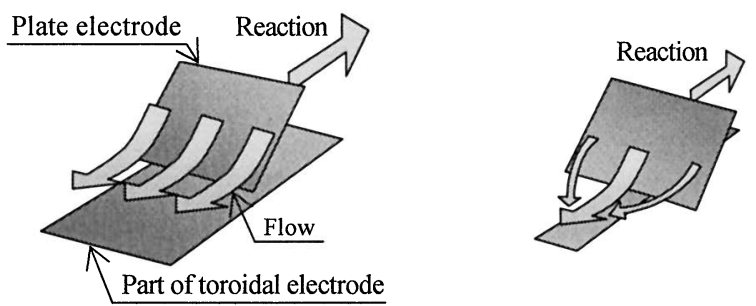

(a) When a toroidal electrode is wide (b) When a toroidal electrode is narrow Fig.15 Performance change by toroidal electrode

\section{EHDモータの評価}

本研究では一般的にEHD現象を発生する電極構造である線 電極と平板電極を改良することで 3 章に示すように新たに平板 電極と環状電極による電極構造を考案した。

この電極は不平等電界を用いることでE HD現象を発生させ る構造であるため，流れの方向に極性をもたず，単純な電界印 加のみでは対流のみが発生し流れを取り出すことが困難である ような流体においても駆動が可能であると考えられる，そのた め，工業的に入手し易いシリコーンオイル等を用いることによ り，安価にアクチュエータの製作が可能であると考えられる.

さらに, 図 3 に示したように, 電極は回転動作を行う平板電 極と容器本体に固定されている環状電極に分離されている構造 であることから，電極への配線を簡素にすることが可能である. また，例えば平板電極を複数個配置するなど，ロー夕側の電極 形状のみを増やすことで高出力化を行うことも可能であり，今 回開発した電極構造は自由度の高い設計が可能であると考えら れる。

\section{7. 結 言}

線電極と平板電極による電極構造を変形し, 傾けた平板電極 と環状電極構造とすることで，E HD現象による流動から力を 取り出し回転運動を発生する電極構造を考案した。さらに, こ の電極構造を応用してEHDモータの製作を行った．これによ り，以下に示す結果を得た。

（1）E HDモータは電圧で無負荷回転数，始動トルクの調整が 可能である.

（2）負荷により出力軸が停止することがあっても電磁モータの ような過電流の発生が少ない.

（3）今回の実験においては平板電極角度 $30^{\circ}$ ，平板電極長さ $7 \mathrm{~mm}$ ，環状電極幅 $20 \mathrm{~mm}$ において最も高い性能を得た。

また，EHDモータは試作段階であるため，今後の課題とし て，流体の液漏れ対策や電極間隔を狭めることによる，低印加 電圧での駆動等の技術的問題の改善，さらに，高出力化を目的 とする平板電極数の増加等の電極配置の検討, 及び解析を行う 予定である。

\section{謝辞}

本論文を執筆するに当たり，流体の提供と助言を頂いた群馬 大学大学院黒田真一准教授に感謝致します. なお, 本研究の一 部は東京電機大学総合研究所助成の下で行った.

\section{参 考 文 献}

1) 数元伊之助: 液状誘電体が電極を上昇する現象, 応用物理, $\mathbf{2 5}$, 6(1956) 264 .

2）赤木徹也, 堂田周次郎, 松下尚史: E HD流体を用いたポンプモジュー ルの試作, 日本機械学会論文集, 68, 673(2002)2614.

3）花岡良一 中道裕之, 高田新三 深見正：EHDポンプと円錐ノズル による液体ジェットの特徴的な流動特性, 電学論 A, 124, 5(2004).

4）服部正行, 関大和, 林鄉裕一, 和泉健吉: ディスク型コロナモータの基 礎的研究, 静電気学会講演論文集, (2002) 201

5）横田眞一, 中田毅: E C F ジェットを㐫用したマイクロアクチュエー タ,フルードパワーシステム, 35, 6(2004)368

6) 横田䢐一, 根本敏之, 近藤豊, 大坪泰文, 枝村一弥: 電界共役流体 (ECF)を応用したマイクロモータ(ロー夕電極(RE)形マイクロ E C F モー夕の提案)，日本機械学会論文集, 66, 651(2000) 3799 .

7) 竹村, 横田, 枝村: 電界共役流体に発生するジェット流を用いたマイク 口人工筋アクチュエータ, 日本機械学会論文集, 71, 708(2005) 2571 .

8）横田, 除 他: 電界共役流体を利用した電子チップ液冷却用平面薄型ポ ンプ, 日本機械学会論文集, 71, 709(2005) 2798 .

9) 竹山説三: 電磁気学現象論, 丸善, (1972)123. 